\title{
The source of fermentable carbohydrates influences the in vitro protein synthesis by colonic bacteria isolated from pigs
}

\author{
J. Bindelle ${ }^{1+}$, A. Buldgen ${ }^{1}$, J. Wavreille ${ }^{2}$, R. Agneessens ${ }^{3}$, J. P. Destain ${ }^{4}$, B. Wathelet ${ }^{5}$ and \\ P. Leterme ${ }^{6}$ \begin{abstract}
Animales, Centre Wallon de Recherches Agronomiques, 8 Rue de Liroux, Gembloux 5030, Belgium; ${ }^{3}$ Section Systèmes Agricoles, Centre Wallon de Recherches Agronomiques, 100 Rue de Serpont, Libramont 6800, Belgium; ${ }^{4}$ Département Production Végétale, Centre Wallon de Recherches Agronomiques, 4 Rue du Bordia, Gembloux 5030, Belgium; ${ }^{5}$ Department of Industrial Biological Chemistry, Gembloux Agricultural University, 2 Passage des Déportés, Gembloux 5030, Belgium; ${ }^{6}$ Prairie Swine Centre Inc., Box 21057, 2105 8th Street East, Saskatoon, Saskatchewan, Canada S7H 5N9
\end{abstract} \\ ${ }^{1}$ Department of Animal Husbandry, Gembloux Agricultural University, 2 Passage des Déportés, Gembloux 5030, Belgium; ${ }^{2}$ Département Productions et Nutrition
}

(Received 23 January 2007; Accepted 18 June 2007)

\begin{abstract}
Two in vitro experiments were carried out to quantify the incorporation of nitrogen $(N)$ by pig colonic bacteria during the fermentation of dietary fibre, including non-starch polysaccharides and resistant starch. In the first experiment, five purified carbohydrates were used: starch (S), cellulose (C), inulin (I), pectin (P) and xylan (X). In the second experiment, three pepsin-pancreatin hydrolysed ingredients were investigated: potato, sugar-beet pulp and wheat bran. The substrates were incubated in an inoculum, prepared from fresh faeces of sows and a buffer solution providing ${ }^{15} \mathrm{~N}$-labelled $\mathrm{NH}_{4} \mathrm{Cl}$. Gas production was monitored. Bacterial $N$ incorporation (BNI) was estimated by measuring the incorporation of ${ }^{15} \mathrm{~N}$ in the solid residue at halftime to asymptotic gas production (T/2). The remaining substrate was analysed for sugar content. Short-chain fatty acids (SCFA) were determined in the liquid phase. In the first experiment, the fermentation kinetics differed between the substrates. $P, S$ and I showed higher rates of degradation $(\mathrm{P}<0.001)$, while $X$ and $C$ showed a longer lag time and $\mathrm{T} / 2$. The sugar disappearance reached $0.91,0.90,0.81,0.56$ and 0.46 , respectively, for $P, I, S, C$ and $X$. Among them, $S$ and I fixed more $N$ per gram substrate $(P<0.05)$ than $C, X$ and $P(22.9$ and $23.2 \mathrm{mg}$ fixed $N$ per gram fermented substrate v. 11.3, 12.3 and 9.8, respectively). Production of SCFA was the highest for the substrates with low N fixation: 562 and $565 \mathrm{mg} / \mathrm{g}$ fermented substrate for $X$ and $C \mathrm{v}$. 290 to 451 for $P, I$ and $S(P<0.01)$. In the second experiment, potato and sugar-beet pulp fermented more rapidly than wheat bran $(\mathrm{P}<0.001)$. Substrate disappearance at $\mathrm{T} / 2$ varied from 0.17 to 0.50 . BNI were 18.3, 17.0 and 10.2 fixed $N$ per gram fermented substrate, for sugar-beet pulp, potato and wheat bran, respectively, but were not statistically different. SCFA productions were the highest with wheat bran (913 mg/g fermented substrate) followed by sugar-beet pulp (641) and potato (556) $(\mathrm{P}<0.05)$. The differences in $N$ uptake by intestinal bacteria are linked to the partitioning of the substrate energy content between bacterial growth and SCFA production. This partitioning varies according to the rate of fermentation and the chemical composition of the substrate, as shown by the regression equation linking BNI to T/2 and SCFA $\left(r^{2}=0.91, \mathrm{P}<0.01\right)$ and the correlation between BNI and insoluble dietary fibre $(r=-0.77, \mathrm{P}<0.05)$ when pectin was discarded from the database.
\end{abstract}

Keywords: dietary fibre, in vitro fermentation, nitrogen excretion, pigs

\section{Introduction}

Increasing attention has been paid to dietary fibre (DF) fermentation, including non-starch polysaccharides (NSP) and resistant starch (RS), in the large intestine of pigs during the past several years. Indeed, DF lowers the energy value of the diet since their digestibility varies from 0.40 to 0.60 compared with the other nutrients (protein, fat, sugars

${ }^{\dagger}$ E-mail: bindelle.j@fsagx.ac.be or starch), which are above 0.80 (Noblet and Le Goff, 2001). On the other hand, the short-chain fatty acids (SCFA) produced by intestinal bacteria due to fibre fermentation can be used by the host animal for his own energy supply. This can cover up to $15 \%$ of the maintenance energy requirements in growing pigs and 30\% in sows (Varel and Yen, 1997). The knowledge of the contribution of DF to energy supply is also important for smallholders in the tropics, since the latter feed their pigs with unconventional fibrous ingredients, such as tree leaves (Leterme et al., 2006). 
The bulking effect of fibre and the prebiotic influence on some intestinal bacterial strains can also benefit the animals by improving satiety, quietness and intestinal health (Williams et al., 2001). It has been shown, however, that some types of DF may increase diarrhoea in piglets (Montagne et al., 2003).

The bacterial growth supported by DF fermentation induces a shift of $\mathrm{N}$ excretion from urea in urine to bacterial protein in faeces and lowers the $\mathrm{pH}$ of the latter (Zervas and Zijlstra, 2002; Martinez-Puig et al., 2003). The protein catabolism in the distal part of the colon and the $\mathrm{NH}_{3}$ emission from the manure are therefore reduced (Nahm, 2003). The relationship between DF fermentability and $\mathrm{N}$ excretion shift is still poorly documented although the source of DF is suspected to influence the growth of the bacterial population (Kreuzer et al., 1998; Zervas and Zijsltra, 2002).

The aim of the present study was to determine in vitro, the amount of protein synthesis by faecal microbes, when (1) starch and different sources of purified NSP, or (2) ingredients differing in DF content, are available as the energy source for microbial fermentation. The kinetics of fermentation and SCFA production were also measured in order to evaluate their relationship with microbial protein synthesis.

\section{Material and methods}

\section{Animals and diets}

The experiments were carried out using three Belgian Landrace sows (weighing from $226 \pm 12$ to $257 \pm 14 \mathrm{~kg}$ ) as sources of bacterial inoculum. The animals were kept in one group and received daily, in two meals (0800 and $1500 \mathrm{~h})$, $3 \mathrm{~kg}$ of a commercial diet (ZENA-D, Quartes, Deinze, Belgium) with the following chemical composition ( $/ \mathrm{kg}$ dry matter (DM)): crude protein (CP), 164; ash, 67; neutraldetergent fibre (NDF), 253; acid-detergent fibre (ADF), 144; acid-detergent lignin (ADL), 29; total DF, 312. The sows had free access to water for the duration of the experiments. The collection of faeces started after 4 weeks of adaptation to the diet.

\section{Substrate}

Experiment 1: fermentation of purified carbohydrates. Five purified sources of fermentable carbohydrates were chosen according to their differences in soluble and insoluble fibre content, constituent sugars and glucosidic bonds (Table 1): potato starch (Fluka 85650), fibrous cellulose (Sigma C6663), inulin (Fibruline, Cosucra, Warcoing, Belgium), citrus pectin (Sigma P-9135) and xylan from oat spelts (Fluka 95590).

Experiment 2: fermentation of sources of fermentable carbohydrates. Sugar-beet pulp (Beta vulgaris), raw potato (Solanum tuberosum) and wheat bran (Triticum aestivum), ground to pass a 1-mm mesh screen by means of a Cyclotec 1093 Sample Mill (FOSS Electric A/S, Hilleroed, Denmark), were used as substrates for in vitro fermentation.

Prior to fermentation, the substrates underwent an in vitro pepsin-pancreatin hydrolysis following the protocol of Boisen and Fernández (1997). In this method, $2 \mathrm{~g}$ samples

Table 1 Chemical composition of the purified carbohydrate sources (experiment 1) and the raw and the pepsin-pancreatin hydrolysed substrates ${ }^{t}$ (experiment 2) (g/kg dry matter)

\begin{tabular}{|c|c|c|c|c|c|c|c|c|c|c|c|}
\hline & \multirow{2}{*}{\multicolumn{5}{|c|}{$\begin{array}{c}\text { Experiment } 1 \\
\text { Purified carbohydrates }\end{array}$}} & \multicolumn{6}{|c|}{ Experiment 2} \\
\hline & & & & & & \multicolumn{3}{|c|}{ Raw substrates } & \multicolumn{3}{|c|}{ Hydrolysed substrates } \\
\hline & Starch & Cellulose & Inulin & Pectin & Xylan & Sugar-beet pulp & Wheat bran & Potato & Sugar-beet pulp & Wheat bran & Potato \\
\hline DM (g/kg diet) & 911 & 958 & 949 & 924 & 957 & 917 & 920 & 944 & 924 & 933 & 909 \\
\hline Ash & 2 & 0 & 0 & 48 & 125 & 73 & 55 & 53 & 82 & 10 & 8 \\
\hline Crude protein & 2 & 1 & 0 & 33 & 2 & 79 & 179 & 100 & 40 & 96 & 7 \\
\hline Fat & - & - & - & - & - & 5 & 33 & 9 & - & - & - \\
\hline Starch & - & - & - & - & - & - & 166 & 672 & - & 0 & 810 \\
\hline NDF & 0 & 874 & 0 & 0 & 115 & 409 & 467 & 93 & 534 & 866 & 111 \\
\hline ADF & 0 & 881 & 0 & 0 & 1 & 223 & 124 & 39 & 323 & 270 & 66 \\
\hline$A D L$ & 0 & 82 & 0 & 0 & 0 & 16 & 34 & 8 & 85 & 76 & 9 \\
\hline Insoluble dietary fibre & 0 & 1000 & 9 & 3 & 328 & 531 & 408 & 99 & 705 & 849 & 101 \\
\hline Total dietary fibre & 0 & 1000 & 34 & 893 & 795 & 682 & 491 & 128 & 896 & 904 & 173 \\
\hline Rhamnose & - & - & - & - & - & - & - & - & 22 & 1 & 2 \\
\hline Fucose & - & - & - & - & - & - & - & - & 1 & 0 & 0 \\
\hline Arabinose & - & 0 & - & - & 58 & - & - & - & 185 & 127 & 7 \\
\hline Xylose & - & 2 & - & - & 515 & - & - & - & 15 & 257 & 4 \\
\hline Mannose & & 1 & - & - & 0 & - & - & - & 13 & 4 & 2 \\
\hline Galactose & - & 0 & - & - & 10 & - & - & - & 48 & 10 & 31 \\
\hline Glucose & 768 & 858 & 38 & - & 43 & - & - & - & 237 & 181 & 10 \\
\hline Fructose & - & - & 961 & - & - & - & - & - & - & - & - \\
\hline Galacturonic acid & - & - & - & 672 & - & - & - & - & 111 & - & - \\
\hline
\end{tabular}

Abbreviations are: $\mathrm{DM}=$ dry matter; NDF = neutral-detergent fibre; $A D F=$ acid detergent fibre; $A D L=$ acid-detergent lignin.

${ }^{\dagger}$ Hydrolysed substrates are the residues of the raw substrates after they have undergone a pepsin-pancreatin hydrolysis according to Boisen and Fernández (1997). 
Bindelle, Buldgen, Wavreille, Agneessens, Destain, Wathelet and Leterme

Table 2 Kinetics parameters of the gas accumulation curves recorded for the purified carbohydrates incubated with sows faecal inoculum and sugars disappearance, bacterial nitrogen incorporation, total short-chain fatty acid production and molar ratios at half-time to asymptotic gas production (experiment 1)

\begin{tabular}{|c|c|c|c|c|c|c|c|c|c|}
\hline & \multicolumn{5}{|c|}{ Substrates } & \multicolumn{2}{|c|}{ Source of variation } & \multicolumn{2}{|c|}{ Variance parameter estimates } \\
\hline & Starch & Inulin & Cellulose & Xylan & Citrus pectin & d.f. & Significance & Period & Residual \\
\hline$n$ & 6 & 6 & 6 & 5 & 6 & & & & \\
\hline \multicolumn{10}{|l|}{ Kinetic parameters $^{\dagger}$} \\
\hline$L(\mathrm{~h})$ & $4.5 c^{4}$ & $4.1^{\mathrm{cd}}$ & $12.7^{\mathrm{a}}$ & $6.5^{\mathrm{b}}$ & $3.6^{d}$ & 4 & $* * *$ & 0.77 & 0.39 \\
\hline$T / 2(h)$ & $8.5^{\mathrm{d}}$ & $11.1^{\mathrm{c}}$ & $23.0^{\mathrm{a}}$ & $17.3^{\mathrm{b}}$ & $8.0^{\mathrm{d}}$ & 4 & $* * *$ & 1.52 & 2.00 \\
\hline$\mu_{t=T / 2}($ per h) & $0.153^{\mathrm{a}}$ & $0.081^{d}$ & $0.074^{d}$ & $0.104^{c}$ & $0.133^{b}$ & 4 & $* * *$ & $1.1 \mathrm{E}-5$ & $16.0 \mathrm{E}-5$ \\
\hline$G_{f}(\mathrm{ml} / \mathrm{g} \mathrm{DM})$ & $405^{b}$ & $393^{c}$ & $396^{\mathrm{bc}}$ & $365^{d}$ & $443^{a}$ & 4 & $* * *$ & 184.0 & 76.2 \\
\hline$n$ & 2 & 2 & 2 & 2 & 2 & & & & \\
\hline Sugar disappearance ${ }^{\ddagger}$ & $0.809^{a}$ & $0.901^{\mathrm{a}}$ & $0.562^{b}$ & $0.458^{b}$ & $0.909^{a}$ & 4 & ** & 0 & 14.3 \\
\hline$n$ & 6 & 6 & 6 & 6 & 6 & & & & \\
\hline BNI (mg/g DM incubated) & $18.5^{\mathrm{a}}$ & $20.7^{\mathrm{a}}$ & $5.7^{\mathrm{b}}$ & $5.8^{\mathrm{b}}$ & $8.8^{b}$ & 4 & ** & 1.59 & 4.15 \\
\hline$n$ & 2 & 2 & 2 & 2 & 2 & & & & \\
\hline BNI (mg/g fermented substrate) & $22.9^{a}$ & $23.2^{\mathrm{a}}$ & $11.3^{\mathrm{b}}$ & $12.3^{\mathrm{b}}$ & $9.8^{b}$ & 4 & * & 2.99 & 9.03 \\
\hline$n$ & 6 & 6 & 6 & 6 & 6 & & & & \\
\hline SCFA (mg/g DM incubated) & $365^{a}$ & $369^{a}$ & $285^{\mathrm{b}}$ & $257^{b}$ & $263^{b}$ & 4 & * & 0 & 618 \\
\hline$n$ & 2 & 2 & 2 & 2 & 2 & & & & \\
\hline $\begin{array}{l}\text { SCFA (mg/g fermented } \\
\text { substrate) }\end{array}$ & $451^{b}$ & $411^{\mathrm{b}}$ & $565^{a}$ & $562^{\mathrm{a}}$ & $290^{c}$ & 4 & ** & 0 & 942 \\
\hline $\begin{array}{l}\text { Molar ratio of acetic/ } \\
\text { propionic/butyric }\end{array}$ & $50: 45: 5$ & $47: 47: 5$ & $44: 55: 1$ & $63: 32: 5$ & $81: 18: 1$ & & & & \\
\hline
\end{tabular}

Abbreviations are: $\mathrm{BNI}=$ bacterial nitrogen incorporation; SCFA = short-chain fatty acid; d.f. $=$ degrees of freedom.

$a, b, c$ For one parameter, means followed by different superscripts in the columns differ at a significance level of 0.05 .

${ }^{\dagger} L$, lag time (h); $T / 2$, half-time to asymptotic gas production (h); $\mu_{t=T / 2}$, fractional rate of degradation at $t=T / 2$ (per $\mathrm{h}$ ); $G_{f i}$ maximum gas volume (ml/g DM).

FProportion of sugars disappeared from the syringe content at half-time to asymptotic gas production.

were weighed in conical flasks. A phosphate buffer solution $(100 \mathrm{ml}, 0.1 \mathrm{~mol} / \mathrm{l}, \mathrm{pH} 6.0)$ and an $\mathrm{HCl}$ solution $(40 \mathrm{ml}$, $0.2 \mathrm{~mol} / \mathrm{l})$ were poured into the flasks. The $\mathrm{pH}$ was adjusted to 2.0 with $1 \mathrm{~mol} / \mathrm{l} \mathrm{HCl}$ or $1 \mathrm{~mol} / \mathrm{l} \mathrm{NaOH}$ and $2 \mathrm{ml}$ of a chloramphenicol solution (Sigma C-0378, $0.5 \mathrm{~g}$ per $100 \mathrm{ml}$ ethanol) was added. Finally, a solution of pepsin $(4 \mathrm{ml}$, 25 g/l, porcine pepsin: 2000 FIP-U/g, Merck no. 7190) was added to the mixture. The flasks were closed with a rubber stopper and placed for $2 \mathrm{~h}$ under gentle agitation in a water-bath at $39 \pm 0.5^{\circ} \mathrm{C}$.

After pepsin hydrolysis, $40 \mathrm{ml}$ of a phosphate buffer solution $(0.2 \mathrm{~mol} / \mathrm{l}, \mathrm{pH} 6.8)$ and $20 \mathrm{ml}$ of a $\mathrm{NaOH}$ solution $(0.6 \mathrm{~mol} / \mathrm{l})$ were added. The $\mathrm{pH}$ was adjusted to 6.8 with $1 \mathrm{~mol} / / \mathrm{HCl}$ or $1 \mathrm{~mol} / \mathrm{l} \mathrm{NaOH}$ and a solution of pancreatin ( $2 \mathrm{ml}, 100 \mathrm{~g} / \mathrm{l}$, pancreatin: Sigma P-1750) was added. The flasks were then closed with a rubber stopper and placed for $4 \mathrm{~h}$ under gentle agitation in a water-bath at $39 \pm 0.5^{\circ} \mathrm{C}$. After hydrolysis, the residues were collected by filtration on a Nylon cloth $(42 \mu \mathrm{m})$, washed with ethanol $(2 \times 25 \mathrm{ml}$ $95 \%$ ethanol) and acetone $(2 \times 25 \mathrm{ml} 99.5 \%$ acetone $)$, dried for $24 \mathrm{~h}$ at $60 \pm 1{ }^{\circ} \mathrm{C}$ and weighed. Enzymatic hydrolysis was performed from 40 to 51 times ( 8 replicates $\times 6$ or 7 periods, according to the substrate). The hydrolysis residues from the different replicates and periods were pooled for subsequent in vitro fermentation.

The DM disappearance (dDM) during the pepsinpancreatin hydrolysis was calculated as follows:

dDM

$=\frac{\text { dry weight of the sample before hydrolysis }- \text { dry weight of the residue }}{\text {. }}$. dry weight of the sample before hydrolysis

The chemical compositions of the raw and hydrolysed substrates are detailed in Table 1.

\section{In vitro fermentation}

In vitro fermentation was performed using the gas test method described by Menke and Steingass (1988) and adapted to the pig by Bindelle et al. (2007). Briefly, an inoculum was prepared from fresh faeces of the three experimental sows. Faeces $(50 \mathrm{~g} / \mathrm{l})$ were mixed to a buffer solution composed of salts and minerals (Menke and Steingass, 1988). The $\mathrm{N}$ source in the buffer solution $\left(\mathrm{NH}_{4} \mathrm{HCO}_{3}\right)$ was replaced by an equimolar quantity of 
Table 3 Dry matter disappearance during the pepsin-pancreatin hydrolysis, kinetics parameters of the gas accumulation curves recorded for the hydrolysed feedstuffs incubated with sows faecal inoculum and sugars disappearance, bacterial nitrogen incorporation, total short chain fatty acid production and molar ratios at half-time to asymptotic gas production (experiment 2)

\begin{tabular}{|c|c|c|c|c|c|c|c|}
\hline & \multicolumn{3}{|c|}{ Substrates } & \multicolumn{2}{|c|}{ Source of variation } & \multicolumn{2}{|c|}{ Variance parameter estimates } \\
\hline & Potato & Sugar-beet pulp & Wheat bran & $\begin{array}{l}\text { substrate } \\
\text { d.f. }\end{array}$ & Significance & Period & Residual \\
\hline$n$ & 51 & 43 & 40 & & & & \\
\hline $\mathrm{dDM}$ & $0.46^{\mathrm{b}}$ & $0.38^{c}$ & $0.57^{\mathrm{a}}$ & 2 & $* * *$ & 0.673 & 7.720 \\
\hline \multicolumn{8}{|l|}{ Kinetic parameters $^{\dagger}$} \\
\hline$n$ & 6 & 6 & 6 & & & & \\
\hline$L(\mathrm{~h})$ & $7.3^{\mathrm{a}}$ & $5.1^{\mathrm{b}}$ & $4.7^{b}$ & 2 & $* * *$ & 2.6 & 1.6 \\
\hline$T / 2(h)$ & $13.9^{a}$ & $12.0^{b}$ & $10.6^{c}$ & 2 & *** & 0.67 & 0.29 \\
\hline$\mu_{t=T / 2}($ per $\mathrm{h})$ & $0.166^{a}$ & $0.152^{\mathrm{a}}$ & $0.128^{b}$ & 2 & *** & $0.00 \mathrm{E}-4$ & $5.23 \mathrm{E}-4$ \\
\hline$G_{f}(\mathrm{ml} / \mathrm{g} \mathrm{DM})$ & $443^{\mathrm{a}}$ & $338^{\mathrm{b}}$ & $189^{c}$ & 2 & $* * *$ & 215 & 545 \\
\hline$n$ & 3 & 3 & 3 & & & & \\
\hline Sugar disappearance ${ }^{\ddagger}$ & $0.50^{\mathrm{a}}$ & $0.40^{\mathrm{a}}$ & $0.17^{b}$ & 2 & ** & 0 & 34.7 \\
\hline$n$ & 9 & 9 & 9 & & & & \\
\hline BNI (mg/g DM incubated) & $8.3^{\mathrm{a}}$ & $7.4 \mathrm{a}$ & $1.7^{b}$ & 2 & ** & 6.43 & 1.75 \\
\hline$n$ & 3 & 3 & 3 & & & & \\
\hline BNI (mg/g fermented substrate) & 17.0 & 18.3 & 10.2 & 2 & NS & 39.9 & 30.8 \\
\hline$n$ & 9 & 9 & 9 & & & & \\
\hline SCFA (mg/g DM incubated) & $275^{a}$ & $249^{b}$ & $151^{c}$ & 2 & $* * *$ & 26 & 113 \\
\hline$n$ & 3 & 3 & 3 & & & & \\
\hline SCFA (mg/g fermented substrate) & $556^{\mathrm{b}}$ & $641^{b}$ & $913^{a}$ & 2 & * & 0 & 8.56 \\
\hline $\begin{array}{l}\text { Molar ratio of acetic/propionic/ } \\
\text { butyric }\end{array}$ & $48: 22: 30$ & $66: 31: 03$ & $60: 36: 04$ & & & & \\
\hline
\end{tabular}

Abbreviations are: $\mathrm{dDM}=$ dry matter disappearance; $\mathrm{DM}=$ dry matter; $\mathrm{BNI}=$ bacterial nitrogen incorporation; SCFA $=$ short-chain fatty acid; d.f. $=$ degrees of freedom.

a,b,c For one parameter, means followed by different superscripts in the columns differ at a significantly $(P<0.05)$.

${ }^{\dagger} L$, lag time (h) level of $0.05 ; T / 2$, half-time to asymptotic gas production (h); $\mu_{t=T / 2}$, fractional rate of degradation at $t=T / 2$ (per $h$ ); $G_{f}$, maximum gas volume $(\mathrm{ml} / \mathrm{g} \mathrm{DM})$.

FProportion of sugars disappeared from the syringe content at half-time to asymptotic gas production.

\footnotetext{
${ }^{15} \mathrm{~N}$-labelled $\mathrm{NH}_{4} \mathrm{Cl}$ (2\% of enrichment, ISOTEC no. T85-70216; Isotech, Miamisburg, $\mathrm{OH}, \mathrm{USA})$. The fermentation at $39^{\circ} \mathrm{C}$ started when $200 \mathrm{mg}$ of one of the substrates and $30 \mathrm{ml}$ of the inoculum were introduced into $100-\mathrm{ml}$ glass syringes.

The experimental scheme was as follows: for experiment 1: 5 substrates $\times 9$ replicates +3 blanks (containing only inoculum), repeated over two periods; and for experiment 2: 3 substrates $\times 9$ replicates +3 blanks, repeated over three periods.

The gas volumes of three syringes per substrate were recorded at regular intervals until $72 \mathrm{~h}$. The six remaining syringes were stopped by quenching in an iced water-bath for $20 \mathrm{~min}$, at half-time to asymptotic gas production, $T / 2$ according to the model of France et al. (1993) presented below. At this moment, half of the final gas volume shown in Tables 2 and 3, was produced in the syringes. This time was determined during a preliminary fermentation run since it differed according to the substrate. At the half-
}

time to asymptotic gas production, the rate of gas production and bacterial growth is in a linear phase, near its maximum.

The syringes were subsequently emptied and rinsed with distilled water $(2 \times 5 \mathrm{ml})$. The fermentation residue of three syringes were pooled and freeze-dried for further determination of residual sugars. The content of the three other syringes were centrifuged $\left(12000 \times \mathrm{g}, 20 \mathrm{~min}, 4^{\circ} \mathrm{C}\right)$. An aliquot of the supernatant (approximately $10 \mathrm{ml}$ ) was taken for SCFA analysis and the rest was discarded. The pellet was suspended in distilled water $(30 \mathrm{ml})$ to dilute traces of ${ }^{15} \mathrm{~N}$ labelled $\mathrm{NH}_{4} \mathrm{Cl}$ originating from the buffer, centrifuged $\left(12000 \times \mathrm{g}, 20 \mathrm{~min}, 4^{\circ} \mathrm{C}\right)$ and the supernatant was discarded. The resulting pellet concentrating the bacterial and the undigested substrate was freeze-dried, weighed and analysed for total $\mathrm{N}$ and ${ }^{15} \mathrm{~N}$-enrichment. For each period, three samples of the inoculum were also taken, centrifuged for further ${ }^{15} \mathrm{~N}$ and SCFA analysis. 


\section{Kinetics of gas production}

Gas accumulation curves recorded during the $72 \mathrm{~h}$ of fermentation were modelled according to France et al. (1993):

$$
\begin{array}{ll}
G(\mathrm{ml} / \mathrm{gDM})=0, & \text { if } 0<t<L, \\
=G_{f}(1-\exp \{-\langle b(t-L)+c(\sqrt{t}-\sqrt{L})\rangle\}) & \text { if } t \geqslant L,
\end{array}
$$

where $G$ denotes the gas accumulation at time $(t), G_{f}(\mathrm{ml} / \mathrm{g}$ DM) the maximum gas volume for $t=\infty$ and $L$ (h) the lag time before the fermentation starts. The constants $b$ (per $\mathrm{h}$ ) and $c\left(\right.$ per $h^{1 / 2}$ ) determine the fractional rate of degradation of the substrate $\mu$ (per $\mathrm{h}$ ), which is postulated to vary with time as follows:

$$
\mu=b+\frac{c}{2 \sqrt{t}}, \text { if } t \geqslant L .
$$

The kinetics parameters ( $G_{f i} L, \mu_{t=T / 2}$ and $\left.T / 2\right)$ were compared in the statistical analysis. $T / 2$ is the half-time to asymptotic gas production when $G=G_{f} / 2$. The syringes that suffered an accidental leakage of gas were discarded.

\section{Measurement of SCFA production at half-time to asymptotic gas production}

Supernatants prepared as described above were filtered using $0.2 \mu \mathrm{m}$ nylon $13 \mathrm{~mm}$ HPLC syringe filter no. 2166 (Alltech Associates Inc., Deerfield, IL, USA) and analysed for SCFA with a Waters 2690 HPLC system (Waters, Milford, $\mathrm{MA}$, USA; $30^{\circ} \mathrm{C}$, with iso-caproic acid as the internal standard) fitted with an HPX 87H column (Bio-Rad, Hercules, CA, USA) combined with a UV detector $(210 \mathrm{~nm})$.

\section{Measurement of $N$ incorporation into microbial cells}

Total $\mathrm{N}$ and ${ }^{15} \mathrm{~N}$-enrichment in the freeze-dried pellets were measured by means of an elemental analyser coupled to an isotope-ratio mass spectrometer (Europa Scientific Ltd, Crewe, UK). Bacterial $\mathrm{N}$ incorporation (BNI, corresponding to $\mathrm{N}$ in the pellet incorporated from the buffer solution into the bacteria) per amount of incubated substrate at $T / 2$ was calculated as follows:

$$
\begin{aligned}
\mathrm{BNI}(\mathrm{mg} / \mathrm{g} \mathrm{DM})= & \left(\frac{\left(\frac{{ }^{15} \mathrm{~N} \times \mathrm{N} \times M_{\text {pellet }}}{0.003663}\right)-\mathrm{N} \times M_{\text {pellet }}}{\left(\frac{0.02}{0.003663}-1\right) \times W}\right) \\
& -\mathrm{BNI}_{\text {inoculum }} \times \frac{V_{0}}{W},
\end{aligned}
$$

where $\mathrm{N}(\mathrm{g} / \mathrm{g})$ denotes the concentration of $\mathrm{N}$ in the pellet, $M_{\text {pellet }}(\mathrm{mg})$ the dry weight of the pellet, 0.003663 the natural enrichment in ${ }^{15} \mathrm{~N}$ of the substrates and the faeces used to prepare the inoculum, 0.02 the enrichment of the mineral buffer in ${ }^{15} \mathrm{~N},{ }^{15} \mathrm{~N}(\mathrm{~g} / \mathrm{g})$ the concentration of ${ }^{15} \mathrm{~N}$ in total $\mathrm{N}$ of the pellet, $V_{0}(\mathrm{ml})$ the volume of inoculum transferred in the syringes at the start of the fermentation and $W(\mathrm{gDM})$ the amount of substrate placed in the syringe.

\section{Chemical analysis}

The raw and hydrolysed substrates and the diet, ground to pass a 1-mm mesh screen by means of a Cyclotec 1093 Sample Mill (FOSS Electric A/S, Hilleroed, Denmark), were analysed for their content in dry matter $\left(105^{\circ} \mathrm{C}\right.$ for $\left.24 \mathrm{~h}\right)$, ash $\left(550^{\circ} \mathrm{C}\right.$ for $8 \mathrm{~h}$ ), nitrogen (Kjeldahl method, $\mathrm{CP}=6.25$ $\times \mathrm{N}$ content), ether extract (Soxhlet method, using ether), NDF (using $\mathrm{Na}_{2} \mathrm{SO}_{3}$ and Termamyl, Novo Nordisk, Bagsværd, Denmark) and ADF and lignin, using the Fibercap system (Foss Electric, Bagsvaerd, Denmark). Starch was determined using amyloglucosidase according to the method of Faisant et al. (1995). Total and soluble dietary fibre (SDF) contents were measured by means of the AOAC 991.43 method (Association of Official Analytical Chemists, 1995), after grinding the samples through a $0.5-\mathrm{mm}$ mesh screen. Constituent sugars of cellulose and xylan were determined as alditol acetates by gas-liquid chromatography (Englyst et al., 1992). The glucose and fructose contents of inulin and the uronic acid content of pectin were determined by high-performance anionexchange chromatography with pulsed amperometric detection (HPAEC-PAD) on a Dionex DX500 chromatrography system (Dionex Corporation, Sunnyville, CA, USA) after enzymatic hydrolysis with endo- and exo-inulinase $\left(50^{\circ} \mathrm{C}\right.$, $24 \mathrm{~h}$ ) and Viscozyme (Realco, Louvain-la-Neuve, Belgium, $\left.50^{\circ} \mathrm{C}, 15 \mathrm{~h}\right)$, respectively.

\section{Statistical analysis}

Statistical analyses were performed using the MIXED procedure of the SAS 8.02 software (Statistical Analysis Systems Institute, 1999) using the following general linear model: for experiment 1 :

$$
Y=\alpha+S_{i}+P_{j}+\varepsilon,
$$

where $Y$ is the result, $\alpha$ the mean, $S_{i}$ the fixed effect of the substrate $(i=1, \ldots, 5), P_{j}$ the random effect of the period $(j=1,2)$ and $\varepsilon$ the error term; and for experiment 2 :

$$
Y=\alpha+S_{i}+P_{j}+\varepsilon,
$$

where $Y$ is the result, $\alpha$ the mean, $S_{i}$ the fixed effect of the substrate $(i=1,2,3), P_{j}$ the random effect of the period $(j=1,2,3)$ and $\varepsilon$ the error term.

\section{Results}

\section{Experiment 1}

The gas accumulation curves recorded during the fermentation of the purified carbohydrates are illustrated in Figure 1 and fermentation kinetics parameters, BNI and SCFA productions of the five carbohydrates are shown in Table 2. 


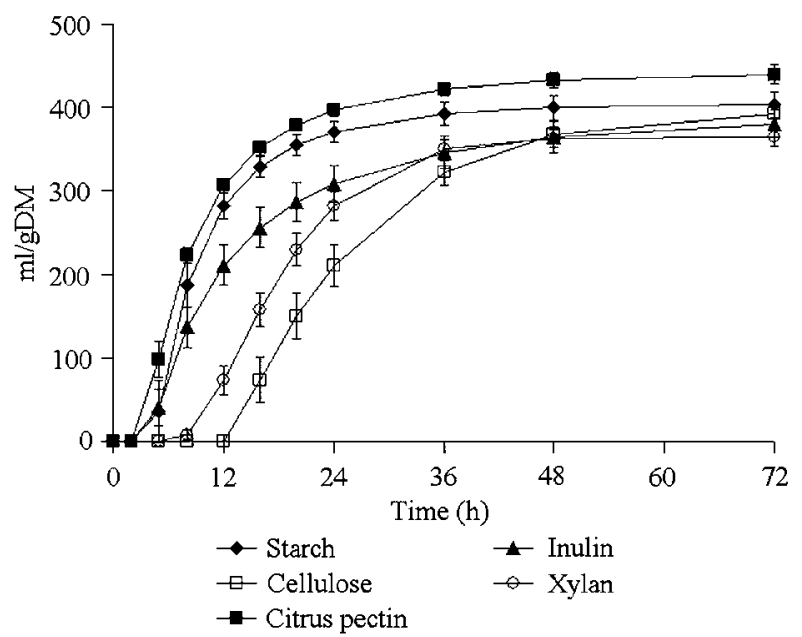

Figure 1 Mean values and standard deviations of the gas production curves recorded during the fermentation of purified carbohydrates incubated with sow faecal inoculum (experiment1).

With the lowest lag $(L)$ and half-time to asymptotic gas production $(T / 2)$, inulin, starch and pectin were the most rapidly fermented substrates $(P<0.001)$. Inulin and cellulose showed lower fractional rates of degradation, compared with starch, pectin and xylan. The final gas production $\left(G_{f}\right)$ also differed between the substrates $(P<0.001)$ : pectin yielded the highest production and xylan the lowest.

Sugar disappearance ranged from 0.8 to 0.9 for inulin, pectin and starch. This indicates that almost all the substrate initially present in the syringe was fermented at $T / 2$ for these fibre sources. For cellulose and xylan, only half of the substrate had been fermented when the fermentation was stopped at $T / 2$. BNI measured at $T / 2$ were higher $(P<0.05)$ for inulin and starch when compared with xylan, cellulose and pectin. The SCFA production for starch and inulin was higher compared with that of pectin, xylan and cellulose $(P<0.025)$. However, cellulose and xylan produced more SCFA per gram of fermented sugars compared with starch and inulin. Pectin yielded the lowest SCFA per gram of fermented sugars. The molar ratio of SCFA showed that a higher proportion of acetate was produced for pectin and xylan compared with the other carbohydrates.

\section{Experiment 2}

The gas accumulation curves recorded during fermentation of the hydrolysed feedstuffs are shown in Figure 2 and kinetics parameters, BNI and SCFA productions are given in Table 3.

Potato yielded the greatest final gas volume $(P<0.001)$ followed by sugar-beet pulp and wheat bran. The latter showed a lower fractional rate of degradation compared with potato and sugar-beet pulp $(P=0.008)$ and had the shortest lag and the earliest half-time to asymptotic gas production $(P<0.001)$.

The rate of sugar disappearance at $T / 2$ ranged from 0.17 for wheat bran to 0.50 for potato. BNI expressed per gram

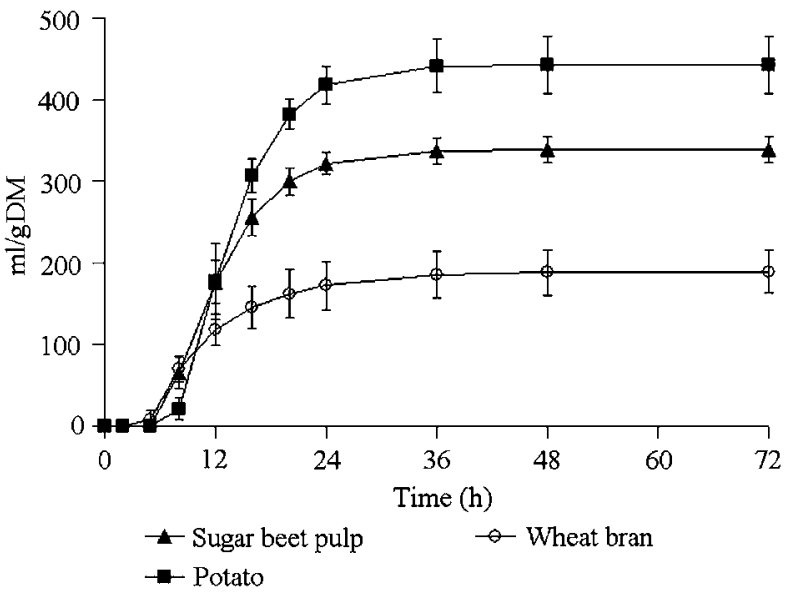

Figure 2 Mean values and standard deviations of the gas production curves recorded during the fermentation of pepsin-pancreatin hydrolysed feedstuffs incubated with sow faecal inoculum (experiment 2).

of incubated substrate was the highest for potato and sugar-beet pulp compared with wheat bran $(P<0.01)$. When BNI was expressed per gram of fermented sugars, the difference observed between wheat bran, potato and sugarbeet pulp became insignificant due to a reduction in the number of observations. Conversely, in experiment 1, there was a difference in BNI between the substrates, even when expressed per gram of fermented sugars. SCFA productions per gram of incubated substrate were the highest for potato followed by sugar-beet pulp and wheat bran $(P<0.001)$. Wheat bran yielded higher SCFA per gram fermented sugars, compared with sugar-beet pulp and potato $(P<0.05)$. The molar ratio also differed between the substrates: potato yielded more butyrate, and sugar-beet pulp and wheat bran produced more acetate. Branched SCFA were not detected during SCFA analysis.

\section{Correlation and regression}

Correlation and regression were calculated throughout experiments 1 and 2 . When pectin was discarded from the database, BNI ( $\mathrm{mg} / \mathrm{g}$ sugar fermented) was correlated to the half-time of asymptotic gas production (T/2) $(r=-0.61$, $P=0.143)$ and to SCFA (mg/g sugar fermented) $(r=-0.72$, $P=0.068$ ) with levels approaching significance. BNI was also correlated to sugar disappearance $(r=0.80$, $P=0.029$ ), to insoluble dietary fibre (IDF) (Table 1) $(r=-0.77, P=0.043)$ and to SDF (starch included in SDF) content of the substrates $(r=0.79, P=0.039)$. A regression equation was calculated linking BNI to SCFA and to T/2. The equation is: BNI ( $\mathrm{mg} / \mathrm{g}$ sugar fermented) $=$ 40.7-0.71 T/2 (h) -0.247 SCFA (mg/g sugar fermented) $\left(r^{2}=0.91, P=0.004\right)$.

\section{Discussion}

The results clearly indicate that the source of dietary carbohydrate influences bacterial protein synthesis during 
colonic fermentation in pigs. The primary function of microbial carbohydrate fermentation is to release ATP, which is required for bacterial cell basal and growth metabolism (Karsli and Russell, 2001). BNI will thus depend on the efficiency of ATP generation from the substrate and on the use of this ATP for the maintenance or growth of the bacteria. The rate of fermentation of carbohydrates depends on their composition and on their structure. Generally, solubility is also linked to rapid fermentation (Hoover and Stokes, 1991) since the swelling and the high water-binding capacity of SDF increase the surface area accessible to bacteria. This is highlighted in this study by the trends towards negative and positive correlation linking BNI to IDF and to SDF (starch included in SDF), respectively.

Two major steps are involved: the hydrolysis of the polysaccharide and the fermentation of the released oligo- and monosaccharides.

$\mathrm{BNI}$ is firstly a consequence of the hydrolysis kinetics. As indicated by the negative correlation between BNI and T/2, high BNI were found among the substrates with high fermentation rates as measured by the low $L$ and $T / 2$ values and the high $\mu_{t=T / 2}$ (Tables 2 and 3,): inulin and starch in experiment 1 and sugar-beet pulp and potato in experiment 2. Cellulose, xylan and wheat bran had lower rates of fermentation and yielded lower BNI values. Hydrolysis is the rate-limiting step of microbial fermentation for cellulose (Noike et al., 1985; Lynd et al., 2002), xylans and arabinoxylans (Strobel and Russell, 1986; Hopkins et al., 2003), contrary to starch, inulin and pectin. When hydrolysis is slow, more energy is required for cell maintenance per unit of time and less energy is available for growth.

The differences in the use of the energy coming from fermentation of substrates for bacterial growth is also reflected by the amount of SCFA produced per gram of fermented substrate (Blümmel et al., 1997). When pectin was discarded from the database, BNI values tended to be negatively correlated with SCFA production $(r=-0.72$, $P=0.068)$. Higher SCFA productions for cellulose and xylan compared with inulin and starch indicate that a lower proportion of the energy content of the substrate was used for growth, since this energy is found in the SCFA. This observation is also applicable when sugar-beet pulp, potato and wheat bran are compared in experiment 2 .

Once the polysaccharides are hydrolysed, the chemical composition of the substrates also influences the pathways of SCFA production, ATP generation and, as a consequence, the BNI. The released monosaccharides support microbial growth with little differences in efficiency (Hoover and Stokes, 1991) since the intestinal bacteria use mainly the Embden-Meyerhof-Parnas pathway, also known as glycolysis, that degrades glucose to pyruvate via glucose-6phosphate (Prescott et al., 1996), for ATP production (Miller and Wolin, 1996). However, xylans and pectins are first metabolised by the pentose-phosphate pathway (Macfarlane and Macfarlane, 2003) starting from the pentose to fructose-6-phosphate and glyceraldehyde-3-phosphate via xylulose-5-phosphate (Prescott et al., 1996). This reduces the bacterial growth rates as reported by Crittenden et al. (2002) who compared xylose and xylo-oligosaccharides with glucose. It explains, beyond the rate of hydrolysis, the lowest BNI values observed for xylan $(515 \mathrm{~g}$ xylose per $\mathrm{kg} \mathrm{DM}$ ) and pectin (672 $\mathrm{g}$ glucuronic acid per $\mathrm{kg} \mathrm{DM}$ ) in experiment 1 and wheat bran ( $251 \mathrm{~g}$ xylose per $\mathrm{kg} \mathrm{DM}$ ) in experiment 2.

The SCFA profiles confirm that different fermentation strategies were used by the bacteria. The production of acetate and butyrate yields $34 \mathrm{mmol}$ ATP per gram SCFA compared with $40 \mathrm{mmol}$ ATP per gram of propionate (Blümmel et al., 1997). Acetate is typical of fermentation under C-limiting conditions (Macfarlane and Macfarlane, 2003). The high production of acetate observed with pectinolytic and xylanolytic bacteria indicates that they recover less energy from the substrate compared with bacteria fermenting starch or fructans which use faster and more energy efficient cycles, leading to higher propionate production. In the case of xylan and wheat bran, high acetate levels are a consequence of low hydrolysis rates that limit the release of monosaccharides. For pectin, this is due to the production of extracellular pectinolytic enzymes (Drochner et al., 2004). The extracellular release of oligosaccharides benefit microbial competitors and reduce the growth of pectinolytic bacteria. On the contrary, Bacteroides, the most abundant saccharolytic genus in the intestine, bind starch to their outer membrane prior to hydrolysis, which prevents any competition with other bacteria (Hooper et al., 2002).

The low BNI yield recorded for pectin, despite a low $T / 2$, a high $\mu_{t=T / 2}$ and low SCFA production, was an exception compared with the other substrates. This is due to the high degree of methoxylation of the pectin used in this study (Sigma-Aldrich, 2006). Methoxylation decreases the growth rate of pectin-fermenting bacteria (Olano-Martin et al., 2002). The methyl group can be esterified with a release of methanol (Drochner et al., 2004) but, unlike glucuronic acid, the methyl group is unusable by pectinolytic bacteria (Hall and Herejk, 2001) for ATP generation and growth.

The $\mathrm{N}$ content of pectin $(32.5 \mathrm{~g}$ CP per $\mathrm{kg} \mathrm{DM})$ and that of the hydrolysed wheat bran $(96.0 \mathrm{~g} / \mathrm{kg} \mathrm{DM})$ decreased the mineral $\mathrm{N}$ uptake from the buffer solution compared with the other fast-fermenting substrates. Intestinal bacteria use ammonia as a major source of $\mathrm{N}$ (Younes et al., 1995). However, microbes that ferment substrates with high levels of $\mathrm{CP}$ recycle the $\mathrm{N}$ content of the substrate protein (Hoover and Stokes, 1991; Cone et al., 2005).

Finally, the in vitro classification of potato, sugar-beet pulp and wheat bran in terms of potential impact on urinary $v$. faecal $\mathrm{N}$ excretion patterns should be combined with in vivo data such as the retention time of the feed in the gastro-intestinal tract. In this study, fermentation was stopped at $T / 2$. This time differs from in vivo residence time in the large intestine.

It can be concluded that the rate of fermentation of the carbohydrates and the chemical composition, the soluble fibre content, the constituent sugars and the $\mathrm{CP}$ content, 
were the major factors that affected bacterial energy production, BNI and SCFA production by the colonic bacteria of pigs. These in vitro observations need to be confirmed through in vivo experiments.

\section{Acknowledgements}

The authors gratefully acknowledge the personnel of the Faculty of Gembloux and the 'Centre wallon de Recherches agronomiques' for their technical assistance. The authors also wish to thank Dr Nicolas Gengler, Dr Marc Culot and Dr Yves Beckers for their help in the statistical analysis and the interpretation of the results and Laura Eastwood for careful correction of the final manuscript.

\section{References}

Association of Official Analytical Chemists 1995. Official methods of analysis, 16th edition. Gaithersburg, MD, USA.

Bindelle J, Buldgen A, Boudry C and Leterme P 2007. Effect of inoculum and pepsin-pancreatin hydrolysis on fibre fermentation measured by the gas production technique in pigs. Animal Feed Science and Technology 132, 111-122. Blümmel M, Makkar HPS and Becker K 1997. In vitro gas production: a technique revisited. Journal of Animal Physiology and Animal Nutrition 77, 24-34.

Boisen S and Fernández JA 1997. Prediction of the total tract digestibility of energy in substrates and pigs diets by in vitro analyses. Animal Feed Science and Technology 68, 277-286.

Cone JW, Jongbloed AW, Van Gelder AH and De Lange L 2005. Estimation of protein fermentation in the large intestine of pigs using a gas production technique. Animal Feed Science and Technology 123, 463-472.

Crittenden R, Karppinen S, Ojanen S, Tenkanen M, Fagerström R, Mättö J, Saarela M, Mattila-Sandholm T and Poutanen K 2002. In vitro fermentation of cereal dietary fibre carbohydrates by probiotic and intestinal bacteria. Journal of the Science of Food and Agriculture 82, 781-789.

Drochner W, Kerler A and Zacharias B 2004. Pectin in pig nutrition, a comparative review. Journal of Animal Physiology and Animal Nutrition 88, 367-380.

Englyst HN, Quigley ME, Hudson GJ and Cummings JH 1992. Determination of dietary fiber as nonstarch polysaccharides by gas-liquid chromatography. The Analyst 117, 1707-1714.

Faisant N, Planchot V, Kozlowski F, Pacouret MP, Colonna P and Champ M 1995. Resistant starch determination adapted to products containing high level of resistant starch. Science des Aliments 15, 83-89.

France J, Dhanoa MS, Theodorou MK, Lister SJ, Davies DR and Isac D 1993. A model to interpret gas accumulation profiles associated with in vitro degradation of ruminant feeds. Journal of Theoretical Biology 163, 99-111.

Hall MB and Herejk C 2001. Differences in yields of microbial crude protein from in vitro fermentation of carbohydrates. Journal of Dairy Science 84, 2486-2493.

Hooper LV, Midtvedt T and Gordon JL 2002. How host-microbial interactions shape the nutrient environment of the mammalian intestine. Annual Review of Nutrition 22, 283-307.

Hoover WH and Stokes SR 1991. Balancing carbohydrates and proteins for optimum rumen microbial yield. Journal of Dairy Science 74, 3630-3644.

Hopkins MJ, Englyst HN, Macfarlane S, Furrie E, Macfarlane GT and McBain AJ 2003. Degradation of cross-linked and non-cross-linked arabinoxylans by the intestinal microbiota in children. Applied Environmental Microbiology 69, 6354-6360.
Karsli MA and Russell JR 2001. Effects of some factors on ruminal microbial protein synthesis. Turkish Journal of Veterinary and Animal Science 25, 681-686.

Kreuzer M, Machmüller A, Gerdemann MM, Hanneken $H$ and Wittman M 1998. Reduction of gaseous nitrogen loss from pig manure using feeds rich in easily-fermentable nonstarch polysaccharides. Animal Feed Science and Technology 73, 1-19.

Leterme P, Botero MM, Londoño AM, Bindelle J and Buldgen A 2006. Nutritive value of tropical tree leaf meals in adult sows. Animal Science 82, 175-184.

Lynd LR, Weimer PJ, van Zyl WH and Pretorius IS 2002. Microbial cellulose utilization: fundamentals and biotechnology. Microbiology and Molecular Biology Reviews 66, 506-577.

Macfarlane S and Macfarlane GT 2003. Regulation of short-chain fatty acid production. The Proceedings of the Nutrition Society 62, 67-72.

Martinez-Puig D, Pérez JF, Castillo M, Andaluz A, Anguita M, Morales J and Gasa J 2003. Consumption of raw potato starch increases colon length and fecal excretion of purine bases in growing pigs. The Journal of Nutrition 133 134-139.

Menke KH and Steingass H 1988. Estimation of the energetic feed value obtained from chemical analysis and in vitro gas production using rumen fluid. Animal Research and Development 28, 7-55.

Miller TL and Wolin MJ 1996. Pathways of acetate, propionate and butyrate formation by the human fecal microbial flora. Applied Environmental Microbiology 62, 1589-1592.

Montagne L, Pluske JR and Hampson DJ 2003. A review of interactions between dietary fibre and the intestinal mucosa, and their consequences on digestive health in young non-ruminant animals. Animal Feed Science and Technology 108, 95-117.

Nahm KH 2003. Influences of fermentable carbohydrates on shifting nitrogen excretion and reducing ammonia emission of pigs. Critical Reviews in Environmental Science and Technology 30, 135-186.

Noblet J and Le Goff G 2001. Effect of dietary fibre on the energy value of feeds for pigs. Animal Feed Science and Technology 90, 35-52.

Noike T, Endo G, Chang JE, Yaguchi Jl and Matsumoto Jl 1985. Characteristics of carbohydrate degradation and the rate-limiting step in anaerobic digestion. Biotechnology and Bioengineering 27, 1482-1489.

Olano-Martin E, Gibson GR and Rastall RA 2002. Comparison of the in vitro bifidogenic properties of pectins and pectic-oligosaccharides. Journal of Applied Microbiology 93, 505-511.

Prescott LM, Harley JP and Klein D 1996. Microbiology, third edition. WCB/ McGraw-Hill, Boston, MA, USA.

Sigma-Aldrich 2006. Pectin from citrus peel. Specification sheet. Retrieved November 16, 2006, from http://www.sigmaaldrich.com/catalog/search/ SpecificationSheetPage/SIAL/P9135.

Statistical Analysis Systems Institute 1999. SAS/STAT User's guide, version 8. SAS Institute Inc., Cary, NC, USA.

Strobel HJ and Russell JB 1986. Effect of pH and energy spilling on bacterial protein synthesis by carbohydrate-limited cultures of mixed rumen bacteria. Journal of Dairy Science 69, 2941-2947.

Varel VH and Yen JT 1997. Microbial perspective on fiber utilization by swine. Journal Animal Science 75, 2715-2722.

Williams BA, Verstegen MWA and Tamminga S 2001. Fermentation in the large intestine of single-stomached animals and its relationship to animal health. Nutrition Research Review 14, 207-227.

Younes H, Demigné C, Behr S and Rémésy C 1995. Resistant starch exerts a lowering effect on plasma urea by enhancing urea $\mathrm{N}$ transfer into the large intestine. Nutrition Research 8, 1199-1210.

Zervas S and Zijlstra RT 2002. Effects of dietary protein and fermentable fiber on nitrogen excretion patterns and plasma urea in grower pigs. Journal of Animal Science 80, 3247-3256. 